changing perceptions about learning by older men in community setting. Contemporary Issues and Perspectives on Gender research in Adult Education. ed. by M. Maksimović, J. Ostrouch-Kamińska, K. Popović, A. Bulajić. Belgrade: ESREA, 173-187. URL: https://cutt.ly/DRLtJqM [in English].

Ostrouch-Kamińska, J., Vieira, C. (2016). Gender sensitive adult education: critical perspective. Revista Portuguesa de Pedagogia. 50-1, 37-55. DOI: https://doi.org/10.14195/1647-8614_50-1_2 [in English].

She figures 2018. (2019). Directorate-General for Research and Innovation. European Commission. 216. URL: https://cutt.ly/BRLylUy [in English].

УДК 374.7:378.1

DOI: https://doi.org/10.35387/od.2(20).2021.20-30

Василенко Олена Вікторівна кандидат педагогічних наук, доцент, профресор кафредри правничої лінгвістики Національної академії внутрішніх справ
Vasylenko Olena - Candidate of Pedagogical Sciences, Associate Professor, Professor of the Legal linguistics Department of the National Academy of Internal Affairs

ORCID iD: http://orcid.org/0000-0002-6364-7317

E-mail: olena-vasylenko@ukr.net

\title{
МОНІТОРИНГ РОЗВИТКУ НАВЧАННЯ ТА ОСВІТИ ДОРОСЛИХ У ГЛОБАЛЬНОМУ ВИМІРІ
}

\begin{abstract}
Анотація. Оглядова стаття присвячена проблемі дослідження й аналізу стану і розвитку навчання та освіти дорослих (НОД) в світі, які здійснюються міжнародними організаціями, зокрема з допомогою Всесвітнього моніторингу розвитку навчання та освіти дорослих, що проводиться Інститутом навчання впродовж життя ЮНЕСКО. Розглянуто ссрери і напрями, які вивчаються у глобальному масштабі, та яким чином зібраний позитивний досвід країн-членів ЮНЕСКО сприятиме подальшому прогресу навчання та освіти дорослих. Рішення регулярно збирати $i$ надавати змістовні інформаційні та аналітичні ресурси щодо розвитку навчання та освіти дорослих, приділяючи особливу увагу проблемі участі в їх окремих видах, було затверджено у "Беленських рамках дій», прийнятих державами-членами ЮНЕСКО у 2009 р. На основі поданих країнами звітів досліджуються наявні моделі участі, приклади ефрективних і неефективних практик у підвищенні рівня загальної участі в НОД і, зокрема, в охопленні найбільш вразливих i малозабезпечених груп населення. Результати дослідження стану НОД на глобальному рівні відображені у серії «Всесвітніх доповідей про навчання та освіту дорослих».

Показано, що әлобальний моніторине є інструментом підведення підсумків поточних змін $i$ аналізу даних, що відображають прогрес, досягнутий в навчанні та освіті дорослих у п'яти сфрерах: політика;
\end{abstract}


управління; фрінансування; якість; участь, інклюзивність і рівність. Наголошується, що при тому, що НОД може сприяти сталому розвитку, більш здоровому суспільству, кращому працевлаштуванню та більш активній громадянській позиції, аналіз даних моніторингу свідчить про нерівномірність участі та відсутність адекватного прогресу у иій сорері, недостатність фрінансування, а також недостатність використання потенціалу навчання та освіти дорослих. Всесвітній моніторине стану навчання та освіти дорослих покликаний привернути увагу всіх країн до важливості мобілізації зусиль і ресурсів для розвитку цієї сфрери, що, в свою чергу, дозволить реалізувати 17 Цілей сталого розвитку тисячоліття.

Ключові слова: навчання та освіта дорослих; всесвітній моніторине; Всесвітня доповідь про навчання і освіту дорослих; Інститут навчання впродовж життя ЮНЕСКО.

\title{
Vasylenko Olena
}

\section{MONITORING OF ADULT LEARNING AND EDUCATION DEVELOPMENT IN THE GLOBAL DIMENSION}

\begin{abstract}
Abstact. The review article is devoted to the problem of research and analysis of the state and development of adult learning and education (ALE) in the world that are conducted by international organizations, namely the Global Monitoring of Adult Learning and Education by the UNESCO Institute for Lifelong Learning. The areas and directions of monitoring that are being studied on a global level are considered in the article, and how the positive experience of the UNESCO member countries will contribute to further progress in the adult learning and education. The decision to regularly collect and provide essential information and analytical resources on the development of adult learning and education, focusing on the issues of participation in individual species, was approved in the "Belen Framework for Action" adopted by the UNESCO member states in 2009. On the basis of country reports there are explored the existing models of participation, examples of effective and ineffective practices in increasing overall participation in $A L E$, and, in particular, in reaching the most vulnerable and low-income groups. The results of the study of the ALE state at the global level are reflected in the series of "Global Reports on Adult Learning and Education".

It has been shown that the global monitoring is a tool for summarizing current changes and analyzing data that reflect the progress made in adult learning and education in five areas: policy; management; financing; quality; participation, inclusiveness and equality. While ALE can contribute to sustainable development, a healthier society, better employment and a more active citizenship, the analysis of monitoring data shows inequality of participation and lack of adequate progress in this sphere, lack of funding and lack of capacity for adult learning and education. The global monitoring of the state of adult learning and education is designed to draw the attention of all countries to the importance of mobilizing efforts and resources for the development of this field, which, in turn, will help to achieve the 17 Millennium Development Goals.
\end{abstract}

Key words: adult learning and education; global monitoring; Global Report on Adult Learning and Education; UNESCO Institute for Lifelong Learning. 
Постановка проблеми, іï актуальність. Навчання та освіта дорослих (НОД) відіграють ключову роль у вирішенні складних завдань, які постають перед суспільством початку XXI ст. Навчання та освіта дорослих дозволяють людям набувати необхідних знань, можливостей, навичок, якостей та ціннісних установок для того, щоб здійснювати і розвивати свої права, управляти своїм життям і розвитком. Ця сфрера освіти також $є$ необхідною для досягнення справедливості та інклюзивності, зменшення масштабів бідності, створення справедливих, терпимих і стійких суспільств, заснованих на грамотності. Головна мета НОД полягає в тому, щоб надавати людям необхідні навички з метою здійснення і реалізації їх прав і контролю над своєю долею. Саме такі підходи були відображені в «Беленських рамках дій», прийнятих на шостій Міжнародній конференції ЮНЕСКО з освіти дорослих CONFINTEA VI в грудні 2009 р., і були підтримані 144 країнами-членами ЮНЕСКО (UIL, 2010).

Вже у 2015 р. було розроблено й прийнято $\mathrm{OOH}$ «Порядок денний у сфері сталого розвитку до 2030 року» та його 17 Цілей сталого розвитку, які ще називають Глобальними цілями, або Цілями розвитку тисячоліття (UN, 2015). У Четвертій Цілі сталого розвитку, присвяченій розвитку освіти, визнано і задекларовано, що освіта $є$ одним з основних прав людини, найціннішим суспільним благом і незамінним інструментом в побудові мирних, стійких і рівноправних суспільств. Оскільки світ змінюється кардинально і швидко, дорослі, які не адаптуються і не підвищують свою кваліфрікацію, «залишаться осторонь» (UIS, 2018).

На основі Цілей сталого розвитку тисячоліття, міжнародною спільнотою було прийнято низку глобальних документів, у яких навчанню та освіті дорослих відводиться особлива роль у сприянні загальному прогресу. Це такі документи, як «Порядок денний в галузі сталого розвитку на період до 2030 року», «Рамкова програма дій Освіта 2030», «Рамкова програма дій щодо здійснення Цілі в галузі сталого розвитку 4», «Інчхонська декларація. Освіта 2030» під назвою «Забезпечення всеохватної й якісної освіти і заохочення можливості навчання протягом усього життя для всіх» та ін.

Також у «Беленських рамках дій» було зафіксовано зобов'язання держав-членів регулярно збирати і надавати інфрормацію про успіх, досягнутий цими країнами у виконанні зобов'язань щодо Цілей сталого розвитку, та глобального розвитку НОД з позиції навчання впродовж життя (UIL, 2009). Таким чином, ЮНЕСКО всіляко сприяло проведенню регулярного моніторингу розвитку НОД в світі, а також всесвітньому діалогу і діяльності в сфері НОД, дозволяючи усім державам розглядати, ділитися, порівнювати і розвивати свої підходи в цьому напрямі.

ЮНЕСКО закликало всі країни забезпечити змістовні інформаційні та аналітичні ресурси, приділяючи особливу увагу проблемам участі в окремих видах НОД, а також незалученості до навчання. Це дозволить обгрунтувати висновки щодо розвитку НОД та можливостей людей брати в них участь, аналізувати переваги навчання для економіки, соціальної сфрери, здоров'я і добробуту. Регулярний моніторинг та аналіз фактичних 
даних країн про участь в НОД сприятиме перегляду політики в цій сфері та інвестуванню в її довгострокове і постійне забезпечення, доступне для всіх учнів, а також дозволить систематично підтримувати попит на освітні послуги з боку тих, хто в минулому був позбавлений можливості навчання. На основі поданих країнами звітів можливо буде дослідити існуючі моделі участі, приклади ефективних і неефективних практик у підвищенні рівня загальної участі в НОД і, зокрема, в охопленні найбільш вразливих і малозабезпечених груп населення з метою розвитку системи НОД для Bcix.

Аналіз актуальних досліджень і публікацій. У перші десятиріччя XXI століття проблеми навчання і освіти дорослих продовжують активно розроблятися зарубіжними й українськими дослідниками, а також в числених документах ЮНЕСКО. Значний внесок у розробку теоретичних основ навчання та освіти дорослих зробили А. Тоуг, Д. Аспін, П. Джарвіс, С. Мерріам, Р. Каффрарелла, Р. Дейв, Дж. Лівінгстон, С. Змєйов, М. Громкова, І. Колесникова та ін. Українськими науковцями також вивчаються різні аспекти освіти дорослих. Теорія і практика освіти дорослих досліджується в працях О. Аніщенко, С. Архіпової, Л. Лук'янової, Н. Ничкало, О. Огієнко та ін. Порівняльно-педагогічні дослідження Н. Авшенюк, О. Баніт, С. Бабушко, Н. Бідюк, Н. Пазюри дозволили проаналізувати досвід розвитку НОД зарубіжних країн, що важливо для становлення вітчизняної андрагогічної науки та її практичного застосування. Слід звернути увагу на засадничі праці Л. Лук'янової, присвячені розробці української «Концепції освіти дорослих» та андрагогічної моделі навчання, в яких обгрунтовано актуальність і важливість розвитку навчання та освіти дорослих в Україні, зумовлених динамікою соціального й науково-технічного прогресу в умовах інформаційно-технологічного суспільства (Лук'янова, 2009; Лук'янова, 2015; Лук'янова 2019).

Метою даної статті $€$ дослідити і проаналізувати, яким чином здійснюється всесвітній моніторинг розвитку навчання та освіти дорослих 3 боку міжнародних організацій, які саме сфери і напрями вивчаються у глобальному масштабі, та яким чином зібраний позитивний досвід країнчленів ЮНЕСКО сприятиме подальшому прогресу НОД в Україні та світі.

Виклад основного матеріалу дослідження. Серед завдань, поставлених перед всіма країнами-членами ЮНЕСКО і сформульованих в «Беленських рамках дій», основними $є$ використання «широких можливостей освіти дорослих в інтересах благополучного майбутнього», i в цьому контексті приділення підвищеної уваги залученості до HOД (UIL, 2009).

Для реалізації визначених планів ЮНЕСКО було прийнято рішення регулярно проводити дослідження стану НОД на глобальному рівні, результати якого відображені у серії «Всесвітніх доповідей про навчання $i$ освіту дорослих» (ВДНОД). Цей документ становить собою інструмент моніторингу, створений для відстеження ходу здійснення «Беленських рамок дій». Дане дослідження складається з низки напрямів, розроблених 
в під керівництвом Інституту навчання впродовж життя ЮНЕСКО (ІЮНВж) у співпраці з Інститутом статистики ЮНЕСКО, а також за участю експертів і незалежних партнерів (UIL, 2009).

3 моменту прийняття БРД було проведено моніторинг i опубліковано чотири «Всесвітні доповіді про навчання і освіту дорослих»: у 2009 р. зібрано дані на основі 129 національних доповідей (UIL, 2009), у 2012 р. Друга всесвітня доповідь містила аналіз даних, поданих 144 країнами-членами ЮНЕСКО, у 2016 р. вийшла Третя всесвітня доповідь, розроблена основі даних опитування та звітів із 139 країн світу, зокрема й України (UIL, 2016). Четверта ВДНОВ у 2019 р. була заснована на даних опитувань, представлених 159 країнами (UIL, 2019).

У прийнятих ЮНЕСКО «Рекомендаціях про навчання і освіту дорослих» у 2015 р. було викладено ті принципи і цілі навчання та освіти дорослих, конкретні шляхи, за допомогою яких країни можуть досягти успіху, і на які мають спрямувати зусилля. В рамках цих рекомендацій визначені три ключові напрями, важливі для НОД, що мають відобразитись у «Всесвітніх доповідях про навчання і освіту дорослих», а саме :

- грамотність та базові навички;

- неперервна освіта та професійний розвиток;

- ліберальна, загальнодоступна і громадянська освіта (UNESCO, 2015).

У кожній доповіді, представленій країнами, міститься огляд останніх даних і відомостей щодо НОД, розглядається передова практика і зобов'язання держав-учасниць щодо вдосконалення НОД із зазначених напрямів. Збираючи та аналізуючи національні доповіді з НОД на основі структурованого опитувальника, держави-учасниці оцінюють свої національні системи та аналізують прогрес у кожній з сфер, визначених у «Беленських рамках дій». Крім того, моніторинг і публікація доповідей супроводжуються низкою заходів, на яких обговорюються отримані результати з різними партнерами. Таким чином, регулярні «Всесвітні доповіді про навчання і освіту дорослих» сприяють самоаналізу, діалогу і взаємному навчанню щодо оцінки НОД і вдосконалення освітньої політики і практики.

Під час проведення моніторингу особлива увага приділяється інформації про моделі нерівності щодо участі деяких груп населення в суспільному житті по всьому світу, зокрема, жінок, етнічних меншин, мігрантів, біженців, людей похилого віку, низькокваліфікованих фахівців, дорослих з обмеженими можливостями і людей, що живуть у віддалених i сільських регіонах. (UIL, 2019). Кінцева мета Всесвітнього моніторингу НОД, що проводиться Інститутом навчання впродовж життя ЮНЕСКО, полягає в підвищенні обізнаності про НОД у всьому світі і пропаганді більш високого рівня зацікавленості з боку осіб, відповідальних за розробку освітньої політики.

В результаті проведеного моніторингу підводяться підсумки поточних змін і аналізу даних, що відображають прогрес, досягнутий в НОД в наступних п'яти сорерах: 1) політика; 2) управління; 3) фрінансування; 4) якість; 5) участь, інклюзивність і рівність (UIL, 2019).

Політика держави щодо НОД у цілому відображає наскільки серйозно держави ставляться до НОД, і якого прогресу вони спроможні 
досягти. При цьому оцінюється прогрес країн по відношенню до таких напрямків політики, як: здійснення законодавства; розробка та реалізація політики; розробка індивідуальних і конкретних планів; залучення зацікавлених сторін; вдосконалення визнання, сертифікації та акредитації неформального і інформального навчання (UIL, 2010).

У ВДНОВ наголошується, що політика кожної держави має будуватися з визнання НОД правом, що надається з метою сприяння особистісному та соціальному розвитку учня незалежно від обставин, тобто, що НОД не повинні обумовлюватися рівнем доходу, місцем розташування, статтю, етнічною приналежністю або здібностями. П'ять основних принципів, на яких ґрунтується розробка політики щодо НОД у країнах-членах ЮНЕСКО передбачають, що НОД - це: складова прав людини на освіту; потенційний засіб досягнення рівності для незахищених груп; можливість безперервного навчання незалежно від його цілей; комплекс заходів у сфері навчання з використанням різних видів навчальної діяльності; довгостроковий підхід до досягнення намічених результатів.

Належне управління НОД сприяє здійсненню політики в галузі навчання і освіти дорослих таким чином, щоб вони були ефективними, прозорими, підзвітними і справедливими. Наявність представників всіх зацікавлених сторін і їх участь необхідні для того, щоб гарантувати задоволення потреб всіх учнів, зокрема найбільш вразливих. При цьому управління НОД визначається як реалізація політики, або «здатність уряду створювати і забезпечувати дотримання правил, а також надавати послуги» (UIL, 2019).

Доведено, що ефективне управління більш повно відповідає потребам усіх учнів і реалізується в таких категоріях, пов'язаних із управлінням, як :

- розширення участі зацікавлених сторін;

- розробка більш ефективних систем моніторингу та оцінки;

- зміцнення співробітництва з громадянським суспільством;

- поліпшення міжгалузевої координації;

- поліпшення міжвідомчого співробітництва;

- поліпшення міжнародного співробітництва;

- зміцнення ініціатив щодо нарощування потенціалу;

- децентралізація.

Фінансування НОД вважається ще однією важливою сферою для оцінки прогресу НОД кожної країни. В останній ВДНОД зазначено, що навчання та освіта дорослих $€$ цінними інвестиціями, які приносять соціальний добробут, створюючи більш демократичні, мирні, інклюзивні, продуктивні, здорові і стійкі суспільства. Значні фінансові інвестиції мають найважливіше значення для забезпечення якісного надання можливостей для навчання дорослих. Надання на систематичній основі фінансової підтримки групам, що перебувають в несприятливому становищі, в рамках будь-якої політики і підходів в галузі освіти можуть включати програми, що надаються безкоштовно або субсидовані урядами, з використанням таких 
стимулів для навчання, як стипендії, звільнення від плати за навчання і оплачувану навчальну відпустку (UIL, 2019).

Аналіз результатів Всесвітнього моніторингу доводить, що успішний розвиток навчання і освіти дорослих можливий за умови здійснення п'яти напрямів діяльності в сфері фінансування, а саме:

1. Прагнути інвестувати не менше $6 \%$ валового національного продукту в освіту в цілому, збільшуючи виділення коштів на НОД.

2. Розширювати ресурси державних департаментів для інтеграції стратегії НОД.

3. Забезпечити міжнародне фінансування програм поширення грамотності і освіти дорослих.

4. Залучати нові джерела фінансування, наприклад, 3 боку приватного сектора, НДО та громад, а також окремих осіб.

5. Приділяти першочергову увагу інвестиціям в безперервну освіту для жінок, сільського населення та осіб з обмеженими можливостями.

Проте, за даними досліджень Інституту навчання впродовж життя ЮНЕСКО, за останні 10 років витрати на НОД продовжували скорочуватися не тільки в країнах з низьким рівнем доходу, а й в країнах 3 середнім і високим рівнем доходу, що свідчить про поступове зменшення уваги до дорослих учнів з боку країн і урядів. 19 \% країн повідомили про витрати менше 0,5\% свого бюджету на НОД і ще $14 \%$ - про витрати менше $1 \%$, проте $19 \%$ з 107 країн доповіли про те, що вони виділяють на цілі НОД більше 4\% свого бюджету на освіту, серед них Німеччина, Зімбабве, Китай, Малайзія, Нова Зеландія, ОАЕ, Таїланд, Фінляндія, Ефіопія, Ямайка. Отже, як підтверджує проведений ЮЮВЖ моніторинг, НОД, як і раніше, недофінансовуються. Така ситуація потребує рішучіх змін, особливо з огляду на те, що в усьому світі налічується 781 млн дорослих, які не вміють читати або писати прості речення (UN, 2015).

Говорячи про якість навчання та освіти дорослих, що також $є$ об'єктом Всесвітнього моніторингу, слід відмітити, що НОД має значення для учня лише за умови високоякісної освіти, і саме така освіта приносить користь як учню, так і суспільству в цілому. «Якість навчання і освіти $€$ цілісною, багатоаспектною концепцією i вимагає постійної уваги i безперервного розвитку», - зазначено у «Беленських рамках дій» (UIL, 2010). Якість навчання дорослих вимагає наявності відповідного змісту і форм навчання, оцінки потреб, орієнтованих на учня, оволодіння численими компетенціями і знаннями, професіоналізму педагогів, збагачення навчального середовища та розширення прав і можливостей окремих осіб і громад.

Якісне забезпечення НОД $€$ «цілісною, багатоаспектною концепцією і практикою», яка повинна регулярно відслідковуватися і оцінюватися з точки зору поліпшення (UIL, 2019). Якість вимагає відповідного змісту, реалізації та оцінки, з тим, щоб надання послуг сприяло розширенню прав і можливостей окремих осіб і громад, а саме, розробки критеріїв оцінки якості навчальних програм, навчальних матеріалів і методологій викладання, розробки методів оцінки результатів 
навчання і покращення умов підготовки та працевлаштування педагогів, які працюють з дорослими.

Більш глибоко можливо визначити якість НОД, виходячи 3 чотирьох особливостей їх забезпечення в країні, а саме:

- методики викладання: педагогічні підходи, орієнтовані на учня, більш актуальні для надання освітніх послуг дорослим, ніж традиційні підходи;

- підготовка кадрів, умови зайнятості і професіоналізм: всі країни визнали важливість підготовки і постійного підвищення кваліфікації викладачів системи НОД;

- системи моніторингу, оцінки та управління якістю: без регулярної оцінки та аналізу якості надання НОД неможливо відстежувати ефективність і дієвість навчання дорослих;

- продовження досліджень з метою інформаційного забезпечення політики і практики: важливий обмін даними і результатами аналізу і, відповідно, знаннями і передовим досвідом в області НОД важливий з метою формування обґрунтованої політики (UIL, 2019).

На основі даних глобального моніторингу, у ВДНОД робиться висновок, що якість навчання і освіти дорослих вимагає не тільки реформ навчальних програм, а й постійної розробки навчальних матеріалів та методологій викладання, необхідних для того, щоб вони були актуальними і ефективними для дорослих у мінливому світі.

Участь, інклюзивність і рівність є одним з ключових аспектів розвитку НОД, що включений до Всесвітнього моніторингу НОД, що проводиться ЮЮВЖ. Участь є ключовим показником для моніторингу доступності і фактичного охоплення НОД і, відповідно, користі від надання НОД. Участь $є$ результатом роботи осіб, які займаються наданням НОД. Надання НОД має бути доступним для всіх учнів, незалежно від доходу, місцезнаходження, статі, етнічної приналежності, інвалідності, мови або будь-якої іншої соціальної, економічної, демографічної або культурної ознаки. Рівний доступ до надання НОД прирівнюється до досягнення соціального розвитку та сприяння миру і процвітання.

Згідно рекомендацій ВДНОД уряди мають можливості доступу до цілого ряду інструментів для розширення і поглиблення участі у НОД. До їх числа входять:

- заходи щодо організації НОД, спрямовані на розширення доступності і забезпечення більш ефективного функціонування НОД;

- цілеспрямоване інвестування, особливо в малозабезпечені верстви населення;

- заходи щодо підвищення попиту, наприклад, стимулювання інтересу шляхом відзначення досягнень в рамках фестивалів і в засобах масової інформації;

- зниження вартості, особливо для бідніших верств населення;

- фрінансове стимулювання для зниження цінових бар'єрів;

- нефінансова стимулювання, таке як: схеми ваучерів, оплачуваних відпусток і можливостей для кар'єрного зростання; 
- надання якісної та своєчасної допомоги, консультацій та рекомендацій всім учням і протягом усього життя;

- стратегії на національному рівні, спрямовані на забезпечення доступу учнів до IKT і навичкам їх використання в повній мірі (UIL, 2019).

У результаті аналізу даних, зібраних під час досліджень в межах Всесвітнього моніторингу у «Четвертій всесвітній доповіді про навчання і освіту дорослих» від 2019 р., наводяться такі висновки.

1) Прогрес в сорері участі в навчанні та освіті дорослих $€$ недостатнім. Держави-члени і міжнародне співтовариство повинні докладати більше зусиль для розширення участі, інвестуючи більше ресурсів і розробляючи ефективну політику, яка спиралася б на передову світову практику, особливо в плані охоплення тих, хто знаходиться в найгіршому становищі.

2) Брак даних $є$ одним з основних перешкод на шляху усунення нерівності в участі в НОД і забезпечення потреб незахищених груп населення. Необхідні додаткові внески в збір і моніторинг даних для сприяння політиці, заснованої на підтверджених фактах, що заохочує загальну участь.

3) Прогрес в області політики і управління НОД є сприятливим, проте він недостатній, і деякі країни, як і раніше відстають в цьому.

4) Фінансування навчання і освіти дорослих $€$ недостатнім. Потрібно більше інвестицій, а також більш цілеспрямована робота з тими, кому найважче надати допомогу.

5) Якість поліпшується, але не в усіх сорерах навчання це відбувається рівномірно. НОД, зокрема, для формування активної громадянської позиції вимагають більш пильної уваги і збільшення інвестицій.

6) Як і раніше існує серйозна і стійка нерівність в питанні участі в НОД, охопленні ключових цільових груп, тож державам слід зосередити свої ресурси на усунення цієї нерівності (UIL, 2019).

Висновки і перспективи подальших досліджень. Отже, на підставі аналізу ключових документів ЮНЕСКО щодо глобального моніторингу стану і розвитку навчання і освіти дорослих в світі можна зробити такі висновки. Навчання та освіта дорослих сприяють особистісному і професійному розвитку, тим самим стимулюючи більш активне залучення дорослих в життя суспільства. НОД сприяють сталому і всебічному економічному зростанню, розширенню можливостей людей щодо працевлаштування, тим самим виступаючи найважливішим інструментом скорочення рівня бідності, поліпшення здоров'я і добробуту людей, формування стійких освітніх спільнот.

Виконуюючи рішення «Беленських рамок дій», Інститут навчання впродовж життя ЮНЕСКО регулярно проводить Всесвітній моніторинг стану і прогресу НОД на глобальному рівні, результати якого відображено у чотирьох «Всесвітніх доповідях про навчання та освіту дорослих». Мета ВДНОД, як інструменту моніторингу НОД у глобальному вимірі, полягає в поглибленні знань про навчання і освіту дорослих в якості одного 3 
ключових компонентів неперервної освіти в усьому світі в інтересах вдосконалення політики, концепцій і практики в сфері освіти в рамках Цілей сталого розвитку тисячоліття. Аналіз даних Всесвітнього моніторингу показує нерівномірність участі і відсутність адекватного прогресу, недостатність фінансування та використання можливого потенціалу навчання і освіти дорослих.

Водночас, моніторинг свідчить про те, що навчання і освіта дорослих приносять значну користь у ряді стратегічно важливих областей, зокрема про позитивну дію на соціальне, громадянське і суспільне життя країн. 3 нього випливає, що навчання і освіта дорослих сприятливо відображаються на здоров'ї і добробуті населення, збільшенні тривалості життя і скороченні числа захворювань при відповідному зниженні витрат на охорону здоров'я. Всесвітній моніторинг НОД підкреслює значні переваги від інвестицій в освіту дорослих для ринку праці та працевлаштування, як для окремих громадян, так і для роботодавців, і для економіки в цілому. Також доведено, що навчання і освіта дорослих зміцнюють соціальну згуртованість, інтеграцію та інклюзивність, збільшують соціальний капітал і розширюють участь в соціальній, громадянській та громадській діяльності. Переваги ці значні, проте, як показує доповідь, розподіляються вони нерівномірно.

Урахування фактичних даних, зібраних країнами про участь та інвестування в довгострокове і постійне забезпечення доступу для всіх учнів, а також про систематичну підтримку попиту на освітні послуги з боку дорослих учнів, покликано сприяти перегляду політики НОД і дозволить цій галузі освіти в повній мірі реалізувати важливий потенціал для досягнення Цілей сталого розвитку тисячоліття.

\section{Список використаних джерел}

Лук'янова, Л. (2015). Акмеологічний ресурс андрагогічної моделі навчання. Проблеми освіти, 84, 31-36.

Лук'янова, Л. (2009). Концептуальні положення освіти дорослих. URL: https://www.rusnauka.com/7_NND_2009/Pedagogica/43099.doc.Htm

Лук'янова, Л. (2019). Освіта впродовж життя в умовах інформаційнотехнологічного суспільства. Освіта дорослих: теорія, досвід, перспективи. 15. 15-20.

UIL. (2009). CONFINTEA VI, Belem Framework for Action: Harnessing the power and potential of adultn learning and education for a viable future. Hamburg, UIL. URL: https://unesdoc.unesco.org/ark:/48223/pf0000187789

UIL. (2009). Global Report on Adult Learning and Education. Hamburg, UIL. URL: https://unesdoc.unesco.org/ark:/48223/pf0000186431

UIL. (2013). The Second Global Report on Adult Learning and Education. Hamburg, UIL. URL: https://unesdoc.unesco.org/ark:/48223/pf0000222407

UIL. (2016). The Third Global Report on Adult Learning and Education. Hamburg, UIL. URL: https://reliefweb.int/sites/reliefweb.int/files/ resources/grale-3.pdf

UIL. (2018). The Fourth Global Report on Adult learning and Education: Monitoring survey. Hamburg, UIL. URL: http://uil.unesco.org/i/doc/adulteducation/grale-4/survey-data/grale-4-survey-printversion. 
UIS. (2018). SDG 4 Data Book: Global education indicators 2018. Montreal, UIS. URL: http://uis.unesco.org/sites/default/files/documents/sdg4-data-book2018-en.pdf

UN. (2015). Sustainable development goals. URL: https://www.ua.undp.org/ content/ukraine/uk/home/sustainable-development-goals.html

UNESCO. (2015). Recommendation on Adult Learning and Education. Hamburg, UIL. URL: https://uil.unesco.org/adult-education/unesco-recommendation/ unesco-recommendation-adult-learning-and-education-2015

\section{References (translated and transliterated)}

Luk'yanova, L. (2015). Akmeologichnyj resurs andragogichnoyi modeli navchannya [Acmeological resource of andragogic model of Navchannia]. Problemy osvity - Problems of education, 84, 31-36 [in Ukrainian].

Luk'yanova, L. (2009). Konceptualni polozhennya osvity doroslyh [Conceptual provision of education for grown-ups.]. URL: https://www.rusnauka. com/7_NND_2009/Pedagogica/43099.doc.Htm [in Ukrainian].

Luk'yanova, L. (2019). Osvita vprodovzh zhyttya v umovah informacijnotehnologichnogo suspilstva [Education for the development of life in the minds of the information and technological support.]. Osvita doroslyh: teoriya, dosvid, perspektyvy - Adult education: theory, experience, prospects. 15. 15-20 [in Ukrainian].

UIL. (2009). CONFINTEA VI, Belem Framework for Action: Harnessing the power and potential of adultn learning and education for a viable future. Hamburg, UIL. $\quad$ URL: $\quad$ https://unesdoc.unesco.org/ark:/48223/pf0000187789 [in English].

UIL. (2009). Global Report on Adult Learning and Education. Hamburg, UIL. URL: https://unesdoc.unesco.org/ark:/48223/pf0000186431 [in English].

UIL. (2013). The Second Global Report on Adult Learning and Education. Hamburg, UIL. URL: https://unesdoc.unesco.org/ark:/48223/pf0000222407 [in English].

UIL. (2016). The Third Global Report on Adult Learning and Education. Hamburg, UIL. URL: https://reliefweb.int/sites/reliefweb.int/files/ resources/grale-3.pdf [in English].

UIL. (2018). The Fourth Global Report on Adult learning and Education: Monitoring survey. Hamburg, UIL. URL: http://uil.unesco.org/i/doc/adulteducation/grale-4/survey-data/grale-4-survey-printversion [in English].

UIS. (2018). SDG 4 Data Book: Global education indicators 2018. Montreal, UIS. URL: http://uis.unesco.org/sites/default/files/documents/sdg4-data-book2018-en.pdf [in English].

UN. (2015). Sustainable development goals. URL: https://www.ua.undp.org/ content/ukraine/uk/home/sustainable-development-goals.html [in English].

UNESCO. (2015). Recommendation on Adult Learning and Education. Hamburg, UIL. URL: https://uil.unesco.org/adult-education/unesco-recommendation/ unesco-recommendation-adult-learning-and-education-2015 [in English]. 